\section{ALA LIBRARY EDUCATION SCHOLARSHIPS}

Individuals, companies, and professional organizations are encouraged to contribute to the general scholarship fund of the American Library Association's Scholarship Program. The number and frequency of the awards, known as the ALA Scholarships, will be determined by the total amount of funds contributed by donors. Each scholarship will be $\$ 2,500$, and as many as possible will be awarded annually.

The program, approved by the ALA Council at the 1969 Midwinter meeting in Washington, D.C., is designed to help worthy students to begin and/or further their library education at the graduate level. Scholarships will be awarded without regard to race, creed, color or national origin. The recipient must enter a formal program of graduate study leading to a degree or advanced certificate at an ALA accredited school.

A jury appointed by the chairman of the ALA Awards Committee in consultation with the incoming president of the Library Education Division will administer the scholarships. The jury will be composed of five members, three of whom are members of LED and two of whom are members of the ALA Awards Committee. The staff liaison to the jury will be LED executive secretary. When funds permit, the recipients of the scholarships will be announced at the inaugural banquet during the ALA annual conferences.

Contributions to the general scholarship fund should be made payable to the American Library Association, 50 East Huron Street, Chicago, Illinois 6061l, and sent to the attention of Mr. David H. Clift, Executive Director.

\section{NEWS EDITOR CHANGES}

Michael Herbison, assistant librarian at Casper College, Casper, Wyoming, has been named News Editor of CRL. Mr. Herbison, who replaces David H. Doerrer, is a recent graduate of the graduate school of library science of the University of Texas.

ACRL Membership

July 31,1969

July 31,1968

July 31,1967

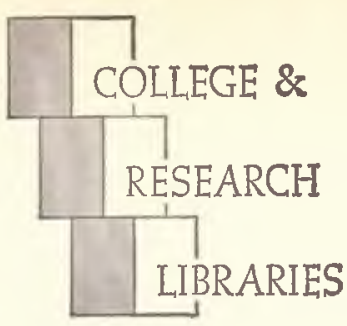

NEW S

ACRL News Issue of College \& Research Libraries

Editor, David Kaser, Comell University Libraries, Ithaca, N.Y. 14850.

News Editor, David Doerrer, Cornell University Libraries, Ithaca, N.Y. 14850.

Editorial Board: JoHn M. DAwson, University of Delaware; Gustave A. Harrer, University of Florida; Samuel Rothsteiv, University of British Columbia; JAMES E. SKIPPER, University of California, Berkeley; Nonman E. TANIs, Kansas State College of Pittsburg; Maurice F. Tauber, Columbia University; EILeEN Thornton, Oberlin College.

ACRL Officers, 1969/70: President, Philip J. McNiff; Chairman, College Libraries Section, John E. Scott; Junior College Libraries Section, Ruthe Erickson; Rare Books Section, Robert J, Adelsperger; Subject Specialists Section, Marcia J. Miller; Agriculture and Biological Sciences Subsection, Howard Rovelstad; Art Subsection, Wolfgang M. Freitag; Educational and Behavioral Science Subsection, Donald Leatherman; Law and Political Science Subsection, Roy M. Mersky; Slavic and East European Subsection, Joseph Placek; University Libraries Section, Roscoe Rouse.

News from the Field, Personnel profiles and notes, classified advertising, official matter of ACRL, and other material of a timely nature is published in the News issues of College \& Research Libraries.

Inclusion of an article or advertisement in $C R L$ does not constitute official endorsement by ACRL or ALA.

Production and Advertising and Circulation office: 50 E, Huron St., Chicago, IIl. 60611. Change of address and orders for subscriptions should be addressed to College of Research Libraries, for receipt at the above address, at least two months before the publication date of the effective issue.

Subscription to $C R L$ is included in membership dues to $A C R L$ of $\$ 6$ or more; other subscriptions to $C R L$ are $\$ 10$ per year. Neither subscriptions nor memberships include miscellaneous unscheduled supplements, which are available by purchase only. Retroactive subscriptions are not accepted. Single journal copies are available at $\$ 1.50$ each and News issues at $\$ 1.00$ each from ALA Publishing Department.

Indexed in Library Literature. Abstracted in Library Science Abstracts. Book reviews indexed in Book Review Index.

College \& Research Libraries is the official journal of the Association of College and Research Libraries, a division of the American Library Association; and is published seventeen times per year-bi-monthly as a technical journal with 11 monthly News issues, combining July-August-at 1201-05 Bluff St., Fulton, Mo. 65251 .

Second-class postage paid at Fulton, Mo. 